\title{
A study on relationship between emotional intelligence and entrepreneurship of trainees in vocational and technical organization
}

\author{
Hossein Ataei Zanjani Nezhad ${ }^{a}$, Mohammad Reza Marjani ${ }^{\mathrm{b}}$ and Amir Najafi ${ }^{\mathrm{c}^{*}}$
}

\begin{abstract}
${ }^{a}$ Department of Management, Zanjan Branch, Islamic Azad University, Zanjan, Iran
${ }^{b}$ Department of Industrial Engineering, Ghom University of Technology, Ghom, Iran

${ }^{c}$ Department of Industrial Engineering, Zanjan Branch, Islamic Azad University, Zanjan, Iran

\section{H R O N I C L E}

Article history:

Received January 2, 2015

Received in revised format 6

February 2015

Accepted 5 March 2015

Available online

March 62015

Keywords:

Emotional intelligence

Trainees

Entrepreneurship skills

Emotional intelligence is defined to guide behavior, thoughts, effective communicating with family and within organizations. The present study aims to investigate the relationship between emotional intelligence and entrepreneurship of trainees in vocational and technical condun in 2014. Method of this study is practical and survey method has been study selects a sample of 300 people. The study uses two questionnaires, one for emotional intelligence based on Bar-On questionnaire and the other for entrepreneurship, which was made by authors. Reliability for Emotional Intelligence Questionnaire was calculated 0.85 by Cronbach's alpha and for entrepreneurship was 0.81 . Data analysis was performed by using SPSS software and the results showed that there was a meaningful and positive relationship between entrepreneurship and all five dimensions of emotional intelligence, including intrapersonal, interpersonal, mood, impulse control and compatibility.
\end{abstract}

\section{Introduction}

Emotional intelligence is hidden story in phenomenon of entrepreneurship. According to McClelland (1965), entrepreneurial process is beyond job, profession and lifestyle and the basis of entrepreneurial infrastructure includes innovation, creativity, love of work, continuous, dynamic, risk-taking, prospective value, idealism, need to progress, positive thinking. This does not mean failure in life as steps for climbing, opportunity to learn, imperfect perception of reality, where the objective is clear and non-profit events are considered for their benefits (Aghayari \& Sharifi Daramadi, 2007). Entrepreneurs are people who have well-developed emotional skills, happy with their lives, their thinking habits are efficient and productive and efficient people, who do not have mastery over their emotional life, involved in internal conflicts from focusing and clear thinking at work (Goleman, 1998, 2006). According to Goleman (1998), emotional intelligence plays an important role in the workplace, 
which is more obvious in favorable performance compared with other cognitive abilities such as intelligence or technical skills. Therefore, by development of emotional intelligence, capabilities of it, organization and its employees will benefit from its advantages.

The importance of emotional intelligence in order to advance status of organizations is increasing. Emotional intelligence can track progress or stagnation staff predicted failure. About $85 \%$ of capabilities in high-level leadership and management for business success depends on emotional intelligence and cognitive other technical skills. According to Goleman (2006) "Person with lack of emotional intelligence, even the best training in the world cannot see prominent and successful, practitioners with high emotionally intelligent leadership work in insurance services, (life insurance, accidents therapy, etc.) and with comparison of their peers who are less emotional intelligence level was twice the average gain absorbs nearly twice customer". Today, one of the basic solutions to deal with this threat arises in developing countries and emphasize on the human element as the most important asset and an inexhaustible source of God. An entrepreneur is someone who defines "need" with effort and perseverance personal products and services to meet the needs, develop, complete and will succeed to exploit and sell products and services in markets. The importance and necessity of entrepreneurs diagnosed in various sectors of industry, trade and services in private sector, unions and government organizations, both for-profit and non-profit are serious and critical. During the last three decades, more than 500 universities in developed countries have created the field of entrepreneurship. Some universities tend to teach fourteen schools and even high school education have expanded (Aghayari \& Sharifi Daramadi, 2007).

Overall, this research attempts to create logical relationship between research and society. The present study tries to anticipate and identify relationship between "emotional intelligence" and "entrepreneurship" of Vocational and Technical Organization of Zanjan, then draw up landscape to its optimum efficiency.

\section{Background}

Salovey and Mayer (1989) considered emotional intelligence as the ability to identify true thoughts and emotions of others, appropriate responses to them and to stimulate awareness of snow up and control their emotional responses. Bar-On (1999) specified five components of intrapersonal, interpersonal, adaptability, impulse control, and general mood to measure the construct of emotional intelligence (Rajai et al., 2008; Rajai, 2010). Singer (2000) defined emotional intelligence using emotional in guiding behavior, thoughts, communicates effectively with colleagues, use of time and how to improve the work. Mayer (2000) and Mayer et al. (1997) developed emotional intelligence where emotional intelligence as cognitive and emotional operating systems check. This model operates in fully integrated model; however, the model consists of four components as follows,

(A) Perception of emotional includes information, identification of emotional system. (B) To facilitate emotional excitement of opinion generally involved use of contemplative branch of excitement to improve cognitive processes; however, directory includes understanding cognitive processing of emotional excitement. (C) Emotional understanding includes processing of emotional information in future and looks ahead to problem. (D) Management of excitement in relation to self and others (BarOn \& Parker, 2000). According to Goleman (1998) Emotional intelligence includes both internal and external elements. Internal elements includes level of self-awareness, self-image, sense of independence and capacity of self-actualization and decisiveness. External elements includes interpersonal relationships, ease of empathy and sense of responsibility. Emotional intelligence also involves capacity to recognize reality, flexibility, ability to solve emotional problems and the ability to cope with stress and shocks (Goleman, 1998). Bar-On (1999) believed that emotional intelligence and emotional skills could develop over time, and could change over the life of the training and breeding programs such as techniques to improve it. 


\subsection{Entrepreneurship}

Entrepreneurship means combining existing resources to new ideas and process of discovery and exploitation of opportunities for value creation. Entrepreneurship is not just the individual and also can be organizations (Thompson et al., 2000).

\subsection{Organizational Entrepreneurship}

According to Mackenzie (2004), entrepreneurial activity may include new product development, which creates effective process. Jennings and Young (1990) defined organizational entrepreneurship as development of new products or markets. Kuratko et al. (2001) described organizational entrepreneurship as creation of new businesses within framework of Mother Company. McGrath (1999) defined organizational entrepreneurship as a tool to enhance economic stability in the long term and Pablos-Mendez and Shademani (2006) believed organizational entrepreneurship to have three dimensions, namely, innovation, development of new products, services or new processes and risks. According to Vesper (1984), organizational entrepreneurship process enables innovative companies and reacts faster than market positions and through sense of ownership motivation boost staff. Schollhammer (1982) knows organizational entrepreneurship as initiatives to protect resources and organization to offer new products and production processes, development and improvement.

Fry (1993) states organizational entrepreneurship as process that if realized would be to encourage, praise, support, and appreciate it. Organizational entrepreneurship is a process through induction of entrepreneurial culture within an organization, to provide product and process innovation in itself. All definitions of entrepreneurship have so far been largely consistent. Key element of organizational entrepreneurship is innovation. According to this theory, every manager or non-manager person in organization has creative talent and creativity dealt with finding new ideas and innovation to make their application to handle (Rezayian, 2005).

\section{Method}

This study is practical and its method for collection data is survey. The population consisted of 500 trainees in Vocational and Technical Organization of Zanjan in May 2014. The sample was calculated as 217 according to Cochrane formula, but the study decided to increase it to 300. A questionnaire was designed based on Raven Bar-On (Baron, 2006) with 50 questions in Likert scale and it was distributed among all 300 participants. To assess the reliability of instruments in this study, Cronbach's alpha was used which in the pilot implementation of Emotional Intelligence Questionnaire was 0.85 and 0.81 for entrepreneurship. Data were analyzed by using SPSS software. In analyzing the collected data, in descriptive statistics level; indicators of frequency, percentage, mean, standard deviation and variance were used and inferential statistics were used to examine relationship between variables in hypothesis of study. All measurement data were normally distributed variables and Pearson correlation coefficient was used.

\subsection{Results}

Hypothesis: There is a relationship between components of emotional intelligence and entrepreneurship of vocational trainees.

To determine the relationship between "components of emotional intelligence" and "entrepreneurship" of vocational trainees in the above hypothesis, given that both variables are measured in interval measurement, Pearson correlation coefficient was used for that data are given in the Table 1. Based on the results of Table 1, it can be seen that the Pearson correlation coefficients for intrapersonal, interpersonal, mood, impulse control and compatibility are $0.133,0.318,0.373,0.370$, and 0.324 , respectively and they are all meaningful. So we can say that there was a relationship between individual components of "emotional intelligence" and "entrepreneurship". The positive sign of Pearson correlation coefficient indicates that all components emotional intelligence positively influence on entrepreneurial skills. 
Table 1

The summary of Pearson correlation test between emotional intelligence and Entrepreneurial skills

\begin{tabular}{ccccccc}
\hline \multicolumn{2}{c}{ Pearson correlation coefficient } & \multicolumn{5}{c}{ Components of emotional intelligence } \\
\cline { 3 - 6 } Entrepreneurial & Correlation & Intrapersonal & Interpersonal & Mood & Impulse control & Compatibility \\
\cline { 2 - 6 } skills. & Sig.(2-tailed) & $.33\left(\left(^{*}\right)\right.$ & $.318(* *)$ & $.373\left({ }^{* *}\right)$ & $.370(* *)$ & $.324(* *)$ \\
& $\mathrm{N}$ & 300 & .000 & .000 & .000 & .005 \\
\hline & & & 300 & 300 & 300 & 300 \\
\hline
\end{tabular}

*Sig. $<0.05, * *$ Sig. $<0.01$

\section{Discussion and Conclusion}

Overall, these findings indicate that there was a direct and positive relationship between entrepreneurship with all five components of emotional intelligence. This means that by increasing the amount of "emotional intelligence" of vocational trainees, entrepreneurs' skills also increase. Goleman (1998, 2006) believed that emotional intelligence was capacity of human knowledge of self and others, and helps determine self-motivate and control people's emotions and relationships with others (Khaef Elahi \& Doustar, 2003). On the other hand, Bar-On (1999) stated that emotional intelligence could include all types of skills, competencies and non-cognitive skills that influence on person's ability to cope with stress and environmental pressures to succeed. Also Hisrich et al. (2002) believed for its unique entrepreneurial economic activity in action, this experience is full of passion, desperation and frustration, anxiety and hard work. As mentioned earlier, it can be understand that entrepreneur in the entrepreneurial process is faced with emotional conflicts, helpless longing and frustration and anxiety. So if that person were not strong he/she would not identify emotional consciousness of desire or inability to failure and chance of success is very low.

A person who has high emotional consciousness can identify the sources of enthusiasm and factor analysis, the use of force as a factor in winning front, anxiety and frustration resources in identifying and planning to reduce the role of these factors. The primary way of recognition of these anxiety, frustration and gain the support of others emotions and feelings of channels can be attracted others to work with satisfaction. This requires high understanding and empathy. If a person is not aware of his/her emotions, perhaps his/her emotions become major obstacle to achieve the goals. On the other hand, entrepreneur needs support and in some cases may even need support from others to interfere and cause emotional conflicts. Entrepreneur must have the ability to efficiently manage emotions to the desire for independence and need to protect and manage emotions of others and balance emotional intelligence. According to Boyatzis (1982), leadership is the characteristics of entrepreneurship. One of the important characteristics of successful leaders is high emotional intelligent. The capabilities and competencies are required for performance of the most critical jobs. Studies show that about two-thirds of the thousands of competencies and capabilities are associated with excellent performance. Social and emotional characteristics such as self-control, flexibility, stability, and ability compromise and win the sympathy of others in fall (Boyatzis, 1982). In leadership positions approximately 90\% of competence and capabilities are necessary for the success, and social-emotional nature.

According to Vesper (1984) someone who leads the others must have full consciousness and Selfmanagement is the first step to self-awareness. Gardner (2011) says leaders are those who speak or act with the clarity of behavior, thoughts and emotions affect certain number of his followers. Managers who are emotionally intelligent leaders are effective. The effective leader is one who works with the maximum quantity and quality, excellent performance, with consent and commitment of staff. Their management takes control of induced character rooted in their emotional intelligence (Khaef Elahi \& Doustar, 2003). Another feature of entrepreneurs is drowning in work, which is in the best state of emotional intelligence. It represents ultimate sinking of excitement for learning or performance is an issue. Caught in the grip of depression, boredom or restlessness from anxiety prevents development of 
sense of being overwhelmed and in delving much in the sense of leading to that person. Indulging mode appears only when a person is at peak of his/her ability, in good condition on skills to dominate his/her brain and neural circuits in the most efficient state of their own position (Goleman, 1998, 2006). When the brain is functioning at peak times such as drowning, exact relationship can be seen between active region and requirements of the task at hand. In this case, even hard work can seem rather boring mood or a more invigorating. Creative enhancements to sink full depend on thought. Indulging in prerequisite dominates industry, profession or art (Goleman et al., 2003). The findings of this study are aligned with existing theories and research of Afzalur Rahim and Minors, (2003), Asadi (2003), Azizi, (2008), Barent, (2005), Caruso et al. (2002), Johnson and Indvik (1999), McColl-Kennedy and Anderson (2002), Palmer et al. (2001) and Weisinger (2006).

\section{References}

Afzalur Rahim, M., \& Minors, P. (2003). Effects of emotional intelligence on concern for quality and problem solving. Managerial Auditing Journal, 18(2), 150-155.

Aghayari, S., \& Sharifi Daramadi, P. (2007). Emotional intelligence agency. Sepahan Press.

Asadi, J. (2003). Investigate the relationship between emotional intelligence and mental burnout Iran Khodro Company. MA Thesis. Allameh Tabatabai University.

Azizi, A. (2008). The value of emotional intelligence in management and organization. Compass Magazine, 89, 58- 56.

Baron, R. M., \& Kenny, D. A. (1986). The moderator-mediator variable distinction in social psychological research: Conceptual, strategic, and statistical considerations. Journal of personality and social psychology, 51(6), 1173.

Baron, R. M. (2006). The Bar-On model of emotional-social intelligence (ESI). Psicothema, 18(1), 1325.

Bar-On, R. E., \& Parker, J. D. (2000). The handbook of emotional intelligence: Theory, development, assessment, and application at home, school, and in the workplace. Jossey-Bass.

Barent, J. M. (2005). Principals' levels of emotional intelligence as an influence on school culture; a dissertation submitted in requirements for the degree of Doctor of Education in Education. Montana State University;

Bar-On, R. (1999). The Emotional Quotient Inventory (EQ-I), a Measure of Emotional intelligence. Toronto, Canada: Multi- Health systems.

Boyatzis, R. E. (1982). The competent manager. New York: Wiley.

Caruso, D. R., Mayer, J. D., \& Salovey, P. (2002). Relation of an ability measure of emotional intelligence to personality. Journal of personality assessment, 79(2), 306-320.

Fry, F. L. (1993). Entrepreneurship: a planning approach. West Group.

Gardner, H. (2011). Frames of mind: The theory of multiple intelligences. Basic books.

Goleman, D. (1998). Working with emotional intelligence. Bantam.

Goleman, D. (2006). Emotional intelligence. Bantam.

Goleman, D., Boyatzis, R., \& McKee, A. (2013). Primal Leadership, With a New Preface by the Authors: Unleashing the Power of Emotional Intelligence. Harvard Business Press.

Hisrich, R. D., \& Peters, M. P. Entrepreneurship (2002). Tata McGraw-Hill (Indian Reprint), 5, 501504.

Khaef Elahi, A. \& Doustar, M. (2003). Dimensions of emotional intelligence. Management and Development, 18, 52-63.

Kuratko, D. F., Ireland, R. D., \& Hornsby, J. S. (2001). Improving firm performance through entrepreneurial actions: Acordia's corporate entrepreneurship strategy. The Academy of Management Executive, 15(4), 60-71.

Jennings, D. F., \& Young, D. M. (1990). An empirical comparison between objective and subjective measures of the product innovation domain of corporate entrepreneurship. Entrepreneurship Theory and Practice, 15(1), 53-66. 
Johnson, P. R., \& Indvik, J. (1999). Organizational benefits of having emotionally intelligent managers and employees. Journal of workplace learning,11(3), 84-88.

McClelland, D. C. (1965). N achievement and entrepreneurship: A longitudinal study. Journal of personality and Social Psychology, 1(4), 389.

McGrath, R. G. (1999). Falling forward: Real options reasoning and entrepreneurial failure. Academy of Management review, 24(1), 13-30.

Mayer, J. (2000). Models of emotional intelligence. In R.,J., Sternberg(Ed), handbook of intelligence. New York: Cambridge University Press, 396-420.

Mackenzie, C. (2004). Policy Entrepreneurship in Australia: A conceptual review and application. Australian Journal of Political Science, 39(2), 367-386.

Mayer, J. D., Salovey, P., Caruso, D. R., \& Sitarenios, G. (2001). Emotional intelligence as a standard intelligence.

McColl-Kennedy, J. R., \& Anderson, R. D. (2002). Impact of leadership style and emotions on subordinate performance. The Leadership Quarterly, 13(5), 545-559.

Palmer, B., Walls, M., Burgess, Z., \& Stough, C. (2001). Emotional intelligence and effective leadership. Leadership \& Organization Development Journal, 22(1), 5-10.

Pablos-Mendez, A., \& Shademani, R. (2006). Knowledge translation in global health. Journal of Continuing Education in the Health Professions, 26(1), 81-86.

Robbins, S. P. (2002). Organizational behavior: Concepts, controversies, and applications. Prentice Hall.

Rezayian, A. (2001). Principles of organization and management. $2^{\text {nd }}$ ed., SAMT Press.

Rajai, A. et al. (2008). The basic relationship between religious belief and identity crisis in youth mental health. Journal of Iranian Psychologists.

Rajai, A. (2010). Spiritual Intelligence: Perspectives and Challenges, a research and educational. Islamic Azad University of Torbatejam, 22, 44-22.

Rezayian, A. (2005). Management principles, SAMT Press.

Salovey, P., \& Mayer, J. D. (1989). Emotional intelligence. Imagination, Cognition and Personality, 9(3), 185-211.

Salovey, P., Bedell, B. T., Detweiler, J. B., \& Mayer, J. D. (2000). Current directions in emotional intelligence research. Handbook of emotions, 2(1), 504-520.

Schollhammer, H. (1982). Internal corporate entrepreneurship. Encyclopedia of entrepreneurship, 209223.

Sternberg, R. J., \& Kaufman, J. C. (1998). Human abilities. Annual review of psychology, 49(1), 479502.

Thompson, J., Alvy, G., \& Lees, A. (2000). Social entrepreneurship-a new look the people and the potential. Management decision, 38(5), 328-338.

Thompson, J., Alvy, G., \& Lees, A. (2000). Social entrepreneurship-a new look at the people and the potential. Management decision, 38(5), 328-338.

Vesper, K. H. (1984). Three faces of corporate entrepreneurship: A pilot study. University of Washington. Graduate School of Business.

Weisinger, H. (2006). Emotional intelligence at work. John Wiley \& Sons. 